\title{
PENGARUH DPK, IMBAL HASIL SBIS, PUAS, DAN TINGKAT INFLASI TERHADAP PEMBIAYAAN BANK SYARIAH DI INDONESIA')
}

Rusida Delfa Kendi Hawa Mahasiswa Program Studi S1 Ekonomi Islam-Fakultas Ekonomi dan Bisnis-Universitas Airlangga Email : delfahawa@ymail.com

Suherman Rosyidi

Departemen Ekonomi Syariah-Fakultas Ekonomi dan Bisnis-Universitas Airlangga

Email : srosyidi@gmail.com

\begin{abstract}
The purpose of this study is to analyze the factors that affect the sharia banking in channeling funds in the period January 2012 to December 2016, both partially and simultaneously. The data used are secondary data, with four independent variables namely DPK, SBIS Return, PUAS, and Inflation Rate which were obtained from official website of Bank Indonesia and OJK, as well as financing data of shariah bank as dependent variable obtained from the official web of Bank Indonesia. The research method used is descriptive quantitative method by using multiple linier regression analysis technique.

The result of the research shows that the four factors in this study, namely DPK, SBIS Return, PUAS, and Inflation Rate, partially as well as simultaneously have a positive and
\end{abstract} significant effect on the channeling of Islamic bank funds.

Keywords: Banks, Sharia Banks, Sharia bank funds distribution, DPK, SBIS Return, Inflation Rate.

I. PENDAHULUAN

Bank syariah merupakan lembaga intermediasi yang mempunyai potensi untuk mengalami kelebihan dan kekurangan likuiditas yang dalam dunia perbankan dikenal dengan istilah masalah likuiditas bank. Masalah likuiditas dapat terjadi oleh ketidakseimbangan antara penghimpunan dana pihak ketiga dan penyaluran dana atau pembiayaan. Masalah likuiditas merupakan masalah yang tidak ringan bagi perbankan pada umumnya dan perbankan syariah pada khususnya. (Prihatiningsih, 2010)

Likuiditas adalah kemampuan bank dalam menyediakan utang jangka pendek apabila bank ditagih oleh pihakpihak yang terkait seperti Dana Pihak Ketiga. Dalam pengelolaan dananya bank dapat mengalami suatu kondisi yaitu kondisi pada posisi seimbang (square), dimana persediaan dana sama dengan dana yang dibutuhkan, posisi lebih (long)

yaitu persediaan dana lebih dari dana yang dibutuhkan, dan posisi kurang (short) yaitu persediaan dana kurang dari dana yang dibutuhkan. (Prihatiningsih, 2010).

Pada masa krisis, perbankan syariah di Indonesia mulai memperlihatkan eksistensinya untuk membantu perbankan nasional. Sejak krisis ekonomi tersebut, beberapa bank konvensional mulai melihat ke sistem bank syariah. Sebagian bank mengkonversi bank konvensionalnya menjadi bank syariah sepenuhnya, sedang sebagian yang lain hanya dengan membuka divisi atau cabang dalam institusinya. (Widodo, 2012).

Penyaluran dana yang dalam perbankan konvensional disebut penyaluran kredit dan dalam sistem perbankan syariah disebut pembiayaan, pembiayaan adalah suatu pengelolaan dana dari pihak bank kepada pihak yang

1). Jurnal ini merupakan bagian dari skripsi dari Rusida Delfa Kendi Hawa. NIM 041311433024 yang diuji pada 7 Agustus 2017. 
Hawa, et al/Jurnal Ekonomi Syariah Teori dan Terapan Vol.5 No. 12 Desember 2018: 998-1012; PENGARUH DPK, IMBAL HASIL SBIS, PUAS, DAN TINGKAT INFLASI TERHADAP PEMBIAYAAN BANK SYARIAH DI INDONESIA

membutuhkan dana. Pembiayaan pada perbankan syariah tentunya memiliki perbedaan dengan kredit pada bank konvensional. Karakteristik yang paling membedakan adalah akad dan produkproduk pembiayaannya. Salah satu akad produk yang khas pada perbankan syariah Indonesia adalah kombinasi berpola bagi hasil dan jual beli, yaitu Mudharabah, Musyarakah dan Murabahah. (Ascarya, 2007)

Pembiayaan pada perbankan syariah dipengaruhi oleh faktor-faktor yang mempengaruhinya yaitu dana yang dihimpun dari masyarakat atau sering disebut dengan istilah Dana Pihak Ketiga (DPK), Imbal hasil Sertifikat Bank Indonesia Syariah (SBIS), Pasar Uang Antarbank Syariah (PUAS), dan tingkat inflasi. Data yang bersumber dari Bank Indonesia menunjukkan bahwa aktivitas pembiayaan yang dilakukan bank syariah meningkat secara berkelanjutan dari tahun ke tahun dalam periode Januari 2012 hingga Desember 2016.

Tabel 1.1

Tabel Total Pembiayaan Bank

\begin{tabular}{|l|l|}
\hline Tahun & $\begin{array}{l}\text { Total Pembiayaan } \\
\text { (dalam milyar } \\
\text { rupiah) }\end{array}$ \\
\hline 2012 & 147.505 \\
\hline 2013 & 184.120 \\
\hline 2014 & 199.330 \\
\hline 2015 & 209.124 \\
\hline 2016 & 240.381 \\
\hline
\end{tabular}
Syari ah Perio de Tahu n 2012 2016
Sumber: Bank Indonesia, 2016.

Tabel 1.1 di atas menunjukkan pembiayaan atau penyaluran dana bank syariah dari tahun 2012 sampai tahun 2016 mengalami peningkatan yang continue.

Penghimpunan Dana Pihak Ketiga (DPK) bank syariah yang bersumber dari masyarakat dalam berbagai bentuk yang dijamin pengembaliannya. Setelah Dana Pihak Ketiga (DPK) dikumpulkan oleh bank, maka bank berkewajiban menyalurkan dana tersebut dalam bentuk pembiayaan. (Nandadipa, 2010).

Bank syariah yang memiliki kelebihan dana, menempatkan kelebihan dananya tersebut ke dalam SBIS atau Sertifikat Bank Indonesia Syariah. SBIS merupakan perangkat kebijakan moneter yang diatur dalam PBI No.12/18/PBI/2010. SBIS adalah tempat untuk menitipkan dana jangka pendek oleh bank syariah pada Bank Indonesia, yang juga berfungsi sebagai simpanan sekunder bagi bank tersebut. Dengan penempatan dana ini maka bank syariah juga memperoleh imbal hasil dari Bank Indonesia.

Faktor lain yang diperhitungkan dalam penyaluran dana kepada masyarakat adalah tingginya risiko pembiayaan sehingga menyebabkan perbankan syariah lebih memilih menempatkan dananya ke dalam SBIS di daripada ke sektor riil. (Widyatsari, 2014)

Pasar vang antar bank atau sering juga disebut interbank call money market Pasar Uang Antar Bank Syariah (PUAS), 
Hawa, et al/Jurnal Ekonomi Syariah Teori dan Terapan Vol.5 No. 12 Desember 2018: 998-1012; PENGARUH DPK, IMBAL HASIL SBIS, PUAS, DAN TINGKAT INFLASI TERHADAP PEMBIAYAAN BANK SYARIAH DI INDONESIA

merupakan salah satu sarana penting untuk mendorong pengembangan pasar vang. Pasar vang antar bank adalah kegiatan pinjam-meminjam dana antara satu bank dengan bank lainnya untuk jangka waktu yang pendek. (Widyatsari, 2014)

Setelah Dana Pihak Ketiga (DPK), Imbal Hasil SBIS, dan PUAS, faktor lain yang dapat mempengaruhi penyaluran dana adalah tingkat inflasi. Kondisi perekonomian yang selalu menarik perhatian perbankan dalam menyalurkan pembiayaan adalah tingkat inflasi. Secara umum inflasi berarti "kenaikan tingkat harga secara umum dari barang atau komoditas dan jasa selama periode tertentu" Karim (2007:135). Inflasi juga dapat dianggap sebagai fenomena moneter karena terjadinya penurunan nilai tukar uang terhadap suatu komoditas. Inflasi dapat diukur dengan tingkat inflasi yaitu tingkat perubahan dari tingkat harga secara umum.

Tingkat inflasi juga dapat mengalami fluktuasi seiring dengan tingkat imbal hasil SBIS karena naik turunnya inflasi menimbulkan dampak kepada individu, masyarakat maupun kegiatan ekonomi secara keseluruhan.

\section{Rumusan Masalah}

Setelah melihat latar belakang yang ada dan agar dalam penelitian ini tidak terjadi kerancuan, maka penulis dapat merumuskan permasalahan yang akan di angkat dalam penelitian ini.
Adapun rumusan masalah yang diambil adalah:

1. Apakah terdapat pengaruh Dana Pihak Ketiga (DPK), Imbal Hasil Sertifikat Bank Indonesia Syariah (SBIS), Pasar Uang Antarbank Syariah (PUAS), dan Tingkat Inflasi secara parsial terhadap kemampuan bank syariah menyalurkan dana periode Januari 2012- Desember 20161?

2. Apakah terdapat pengaruh Dana Pihak Ketiga (DPK), Imbal Hasil Sertifikat Bank Indonesia Syariah (SBIS), Pasar Uang Antarbank Syariah (PUAS), dan Tingkat Inflasi secara simultan terhadap kemampuan bank syariah menyalurkan dana periode Januari 2012- Desember 2016 ?

\section{Tujuan Penelitian}

1. Untuk mengetahui pengaruh Dana Pihak Ketiga (DPK), Imbal Hasil Sertifikat Bank Indonesia Syariah (SBIS), Pasar Uang Antarbank Syariah (PUAS), dan Tingkat Inflasi terhadap kemampuan bank syariah dalam menyalurkan dana secara sendiri-sendiri.

2. Untuk mengetahui pengaruh Dana Pihak Ketiga (DPK), Imbal Hasil Sertifikat Bank Indonesia Syariah (SBIS), Pasar Uang Antarbank Syariah (PUAS), dan Tingkat Inflasi terhadap kemampuan bank syariah dalam menyalurkan dana secara simultan. 
Hawa, et al/Jurnal Ekonomi Syariah Teori dan Terapan Vol.5 No. 12 Desember 2018: 998-1012; PENGARUH DPK, IMBAL HASIL SBIS, PUAS, DAN TINGKAT INFLASI TERHADAP PEMBIAYAAN BANK SYARIAH DI INDONESIA

\section{TINJAUAN PUSTAKA}

\section{Bank Syariah}

Seperti Undang-undang No. 7 Tahun 1992 tentang Perbankan yang diperbaharui dengan Undang-undang No. 10 Tahun 1998, "yang dimaksud dengan Bank adalah badan usaha yang menghimpun dana dari masyarakat dalam bentuk simpanan dan menyalurkannya kepada masyarakat dalam bentuk kredit dan atau bentubentuk lainnya dalam rangka meningkatkan taraf hidup rakyat banyak."

Bank di Indonesia semakin kaya dengan munculnya system keuangan syariah yang salah satunya adalah perbankan syariah. Menurut Prihatiningsih, (2014) pada dasarnya, bank konvensional dan bank syariah memiliki persamaan fungsi yaitu untuk bisnis, intermediary, dan menyalurkan dana. Selain itu, bank konvensional dan bank syariah memiliki perbedaan di dalam system operasinya, bank syariah adalah bank yang beroperasi tanpa menggunakan dan tidak berbasis bunga, melainkan menggunakan prinsip bagi hasil yang berasaskan kejujuran, kemitraan dan etika berinvestasi untuk memberikan efek yang adil antara bank dan masyarakat itu sendiri.

Sistem perbakan syariah adalah sistem perbankan yang menerapkan nilainilai syariah, yang salah satunya adalah pelarangan riba/ bunga. Dihindarinya riba di dalam system perbankan syariah merupakan keharusan karena didasari oleh perintah agama, seperti yang telah dijelaskan dalam ayat Al Qur'an sebagai berikut:

Surat Al-Baqarah [2] ayat 275 :

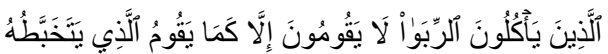

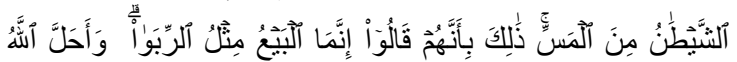

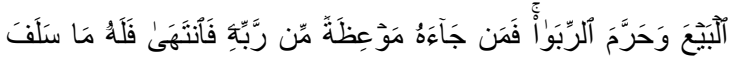

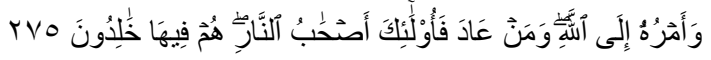

Allaẓina ya' kulūna 'r-ribā lā yaqūmūna illā kamā yaqūmu 'I-laẓi yatakhabbațuhu syayțānu mina 'I-massi. żālika bi-annahum qālū innamā 'I-bay'u mislu 'r-ribā. wa-aḥalla allāhu albay' waharrama rribā faman jā-ahu mau'izatun min rabbihi faintahā falahu m salafa waamruhu ilā allāh waman 'āda faulā-ika aśḥābu nnāri. hum fịhā hạalidūna.

"Orang-orang yang memakan riba tidak dapat berdiri melainkan seperti berdirinya orang yang kemasukan setan karena gila. Yang demikian itu karena mereka berkata bahwa jual beli itu sama dengan riba. Padahal Allah telah menghalalkan jual beli dan mengharamkan riba. Barang siapa mendapat peringatan dari Tuhannya, lalu dia berhenti, maka apa yang telah diperolehnya dahulu menjadi miliknya dan urusannya (terserah) kepada Allah. Barang siapa mengulangi, maka mereka itu penghuni neraka, mereka kekal didalamnya."

\section{Sumber Pendapatan Bank Syariah}

Sumber pendapatan bank syariah terdiri dari (Sudarsono, 2005:55):

1. Bagi hasil atas kontrak mudharabah dan kontrak musyarakah 
Hawa, et al/Jurnal Ekonomi Syariah Teori dan Terapan Vol.5 No. 12 Desember 2018: 998-1012; PENGARUH DPK, IMBAL HASIL SBIS, PUAS, DAN TINGKAT INFLASI TERHADAP PEMBIAYAAN BANK SYARIAH DI INDONESIA

2. Keuntungan atas kontrak jual-beli (al-bai')

3. Hasil sewa atas kontrak ijarah

4. Fee dan biaya administrasi atas jasa-jasa lainnya.

Faktor-Faktor yang Mempengaruhi Bank Syariah Menyalurkan Dana

1 Dana Pihak Ketiga (DPK)

Dana Pihak Ketiga adalah danadana yang dihimpun dari masyarakat, dan merupakan sumber dana terbesar yang paling diandalkan oleh bank (bisa mencapai $80 \%-90 \%$ dari seluruh dana yang dikelola oleh bank) (Dendawijaya, 2010). Dana yang berasal dari masyarakat ini bersumber dari individu, perusahaan, pemerintah, rumah tangga, koperasi, yayasan dan lain-lain. Dana yang diterima oleh bank dapat dimanfaatkan agar menjadi pendapatan. Menurut Rahmat Dahlan, (2015) Bank dapat memanfaatkan dana tersebut dengan cara menyalurkan dana kepada masyarakat melalui pembiayaan. Selain itu bank juga dapat menitipkan sebagian dananya ke Bank Indonesia dalam bentuk Sertifikat Bank Indonesia Syariah (SBIS). Semakin besar pembiayaan yang dapat dilakukan oleh bank, maka semakin besar pula kesempatan bank untuk mendapatkan keuntungan, dan hal ini akan membuat bank semakin tertarik untuk meningkatkan penyaluran dananya.

\section{Imbal Hasil Sertifikat Bank Indonesia Syariah (SBIS)}

Di Indonesia, salah satu instrumen operasi moneter syariah adalah Sertifikat Bank Indonesia Syariah (SBIS). Agar pasar dapat berfungsi dengan baik berdasarkan prinsip syariah, maka otoritas moneter menciptakan suatu alat untuk mengendalikan uang yang beredar sesuai dengan prinsip syariah. Mula-mula, Bank Indonesia menggunakan Serifikat Wadiah Bank Indonesia (SWBI) sesuai dengan PBI No. 6/7/PBI/2004 tanggal 16 Februari 2004. Dalam perkembangannya, SWBI ini diganti dengan instrumen Sertifikat Bank Indonesia Syariah (SBIS) sesuai dengan PBI No.10/1 1/PBI/2008 tanggal 31 Maret 2008. Pengertian SBIS adalah surat berharga berdasarkan prinsip syariah berjangka waktu pendek dalam mata uang rupiah yang diterbitkan oleh Bank Indonesia.

SBIS merupakan salah satu mekanisme yang digunakan Bank Indonesia untuk mengontrol kestabilan nilai rupiah. Instrumen ini memiliki fungsi sebagai instrument Operasi Pasar Terbuka yang bertujuan untuk mengendalikan kestabilan nilai rupiah dan tingkat inflasi. Dengan menjual SBIS, maka Bank Indonesia dapat menyerap kelebihan vang yang beredar.

SBIS dijual melalui mekanisme lelang dan berfungsi sebagai instrumen moneter Islam yang utama bagi bank sentral selain cadangan minimum. Bank sentral memberi imbalan atau fee kepada bank yang membeli SBIS dan tingkat imbalannya mengacu pada suku bunga SBI. Bank syariah yang menempatkan 
Hawa, et al/Jurnal Ekonomi Syariah Teori dan Terapan Vol.5 No. 12 Desember 2018: 998-1012; PENGARUH DPK, IMBAL HASIL SBIS, PUAS, DAN TINGKAT INFLASI TERHADAP PEMBIAYAAN BANK SYARIAH DI INDONESIA

dana pada SBIS berhak mendapatkan upah (ujrah ju'alah) atas jasa membantu memelihara keseimbangan moneter Indonesia. Pihak yang dapat ikut serta dalam lelang SBIS adalah Bank Umum Syariah (BUS), Unit Usaha Syariah (UUS), atau pialang yang bertindak atas nama BUS/UUS.

\section{Pasar Uang Antarbank Syariah (PUAS)}

Untuk memenuhi kebutuhan likuiditas, bank-bank syariah juga memerlukan akses ke pasar vang, baik dalam rangka penanaman dana yang sementara waktu belum digunakan maupun untuk memenuhi kebutuhan dana dengan segera. Bank syariah dapat mengalami kekurangan likuiditas disebabkan oleh perbedaan jangka waktu antara penerimaan dan penanaman dana, dapat pula mengalami kelebihan likuiditas disebabkan dana yang terhimpun belum dapat disalurkan kepada pihak yang memerlukan. Dalam rangka memenuhi kekosongan tersebut, maka dibutuhkan instrumen-instrumen likuiditas.

$$
\text { Pasar Uang Antarbank }
$$

Berdasarkan Prinsip Syariah (PUAS) adalah kegiatan investasi jangka pendek dalam rupiah antar peserta pasar berdasarkan prinsip mudharabah, yaitu perjanjian antara pemilik dana dan pengelola dana untuk melakukan kegiatan usaha guna memperoleh keuntungan, dan keuntungan tersebut akan dibagikan kepada kedua belah pihak berdasarkan nisbah yang telah disepakati sebelumnya (Arifin, 2009).

\section{Tingkat Inflasi}

Inflasi menjadi salah satu indikator makro ekonomi yang penting dalam perekonomian Indonesia. Semua perekonomian mengalami inflasi dan tidak ada satupun negara yang kebal terhadap penyakit ekonomi yang satu ini. Mengenai penyebab inflasi, Putong (2003:254) menyatakan, "Inflasi adalah proses kenaikan harga-harga umum secara terus menerus. Akibat dari inflasi secara umum yaitu menurunnya daya beli masyarakat dikarenakan secara ritel tingkat pendapatannya juga menurun". Menurut teori jumlah vang, the quantity theory of money Irving Fisher, bahwa jumlah vang yang tersedia pada perekonomian menentukan nilai uang dan pertumbuhan jumlah vang merupakan penyebab utama terjadi inflasi.

Menurut Sukirno (2004: 333), berdasarkan pada sumber atau penyebab kenaikan harga-harga yang berlaku, tingkat inflasi biasanya dibedakan kepada tiga bentuk, yaitu:

a. Inflasi tarikan permintaan. Inflasi ini biasanya terjadi pada masa perekonomian berkembang pesat. Kesempatan kerja yang tinggi menciptakan tingkat pendapatan yang tinggi dan selanjutnya menimbulkan pengeluaran yang melebihi kemampuan ekonomi memproduksi barang dan jasa. 
Hawa, et al/Jurnal Ekonomi Syariah Teori dan Terapan Vol.5 No. 12 Desember 2018: 998-1012; PENGARUH DPK, IMBAL HASIL SBIS, PUAS, DAN TINGKAT INFLASI TERHADAP PEMBIAYAAN BANK SYARIAH DI INDONESIA

Pengeluaran yang berlebihan inilah yang akan menimbulkan inflasi.

b. Inflasi desakan biaya. Inflasi seperti ini merupakan bentuk inflasi yang diakibatkan oleh perkembangan yang tidak seimbang diantara permintaan dan penawaran barang dalam perekonomian. Setiap masyarakat tidak dapat secara mendadak menaikkan produksi berbagai macam barang ketika permintaan meningkat.

C. Inflasi diimpor. Inflasi ini terjadi apabila barang-barang impor yang mengalami kenaikan harga di negeri asalnya. Contohnya, jika Negara kita mengimpor faktor-faktor produksi (berupa bahan baku dan mesin) serta mengimpor barang-barang jadi (seperti motor, mesin cuci, dan sebagainya) dari Jepang, maka jika Jepang mengalami kenaikan harga atau inflasi, otomatis Negara kita juga akan mengalami inflasi. Sebab barangbarang yang kita dapat dari Jepang tentu akan lebih mahal, dan barangbarang di Jepang pun juga dijual lebih mahal.

Keterangan Sukirno tersebut senada dengan yang diterangkan oleh Samuelson mengenai penyebab inflasi yaitu demand pull inflation (1995:584) dan cost push inflation (1995:585. Selain kedua penyebab inflasi tersebut, Samuelson masih menambah satu lagi, inertial inflation (1995:584) yakni "we can compare inertial inflation to a lazy old dog. If the dog is not "shocked' by the push of a foot or the pull of a cat, it will stay where it is. Inertial inflation occurs when the $A S$ and $A D$ curves are moving steadily upward at the same rate."

Selain itu juga, Menurut Sukirno (2004), inflasi dapat digolongkan menurut besarannya, yaitu:

(i) Inflasi ringan atau low inflation, yang disebut juga dengan inflasi satu digit yaitu inflasi di bawah 10\% per tahun. Inflasi ini masih dianggap normal. Dalam rentang inflasi ini orang masih percaya pada uang dan masih mau memegang uang.

(ii) Inflasi sedang atau galloping inflation atau double digit inflation yakni inflasi antara $20 \%$ sampai $100 \%$ per tahun. Inflasi seperti ini terjadi karena permintaan lemah, perang, revolusi dan kejadian lain yang menyebabkan barang tidak tersedia sementara vang berlimpah, sehingga orang tidak percaya pada vang. Orang hanya memegang uang seperlunya saja, sedangkan kekayaan disimpan pada aset-aset riil.

(iii) Inflasi di atas 200\% per tahun atau hyperinflation. Dalam keadaan seperti ini, orang tidak percaya pada vang. Masyarakat berpandangan lebih baik membelanjakan vang dan menyimpan dalam bentuk barang seperti emas, tanah, bangunan, karena barang jenis ini kenaikan harganya setara dengan inflasi. Inflasi yang sangat berbahaya ini muncul karena kehancuran sosial dan runtuhnya aktivitas perekonomian, kedua, ketidakmampuan pemerintah untuk 
Hawa, et al/Jurnal Ekonomi Syariah Teori dan Terapan Vol.5 No. 12 Desember 2018: 998-1012; PENGARUH DPK, IMBAL HASIL SBIS, PUAS, DAN TINGKAT INFLASI TERHADAP PEMBIAYAAN BANK SYARIAH DI INDONESIA

mengamankan situasi serta kehilangan kekuasaan terhadap rakyat, ketiga, terjadinya perang yang menghancurkan, seperti yang terjadi terhadap mata vang Irak setelah perekonomian Negara tersebut diboikot dan diserang Amerika dan sekutunya.

\section{III.METODE PENELITIAN}

\section{Pendekatan Penelitian}

Pendekatan penelitian yang akan digunakan dalam penelitian ini adalah pendekatan kuantitatif. Menurut Anshori dan Iswati (2009:13) pendekatan kuantitatif adalah "penelitian terstruktur dan mengkuantifikasikan data untuk dapat digeneralisasikan." Pendekatan kuantitatif ini bertujuan untuk mengetahui hubungan antar variabel yang menitikberatkan pada pengujian hipotesis sehingga diharapkan dapat menjawab rumusan masalah yang telah ditetapkan.

\section{Jenis dan Sumber Data}

Penelitian ini menggunakan jenis data sekunder dan runtut waktu (time series). Data sekunder merupakan data yang telah dikumpulkan oleh lembaga pengumpul data dan di publikasikan pada masyarakat pengguna data (Mudrajat, 2003:127). Data time series yang digunakan meliputi periode tahun 2012 hingga 2016.

Data penyaluran dana perbankan syariah diperoleh dari Statistik Perbankan Syariah (SPS) yang dipublikasikan oleh Bank Indonesia melalui website Bank Indonesia pada periode bulanan mulai dari Januari 2012 sampai dengan
Desember 2016. Data DPS, Imbal hasil SBIS, PUAS dan tingkat inflasi juga diperoleh dari website resmi Bank Indonesia

\section{Teknik Analisis}

Teknik analisis yang digunakan dalam penelitian ini adalah dengan regresi linier berganda. Regresi linier adalah alat statistik yang dipergunakan untuk mengetahui pengaruh antara satu atau beberapa variabel terhadap satu buah variabel. (Tri Basuki, 2016).

Analisis regresi linier merupakan metode statistik yang paling jamak dipergunakan dalam penelitian-penelitian sosial, terutama penelitian ekonomi, dengan program computer yang paling banyak digunakan adalah SPSS (Statistical Package For Service Solutions).

\section{IV.HASIL DAN PEMBAHASAN}

\section{Deskripsi Hasil Penelitian}

Dari Tabel output hsil regresi, terlihat nilai adjusted $R^{2}$ sebesar 0,984, artinya variabel independen dapat menjelaskan variabel dependen sebesar $98,4 \%$, sedangkan $1,6 \%$ dijelaskan oleh faktor lain yang tidak terdapat dalam model.

Tahap selanjutnya adalah Uji $\mathrm{F}$ yakni untuk mengetahui pengaruh variabel independen (DPK, Imbal Hasil SBIS, PUAS dan tingkat inflasi) secara simultan atau bersama-sama mempengaruhi variabel dependen (penyaluran dana bank syariah), yang ditunjukkan dalam tabel ANOVA.

Berdasarkan tabel ANOVA, ternyata nilai signinifikansi adalah sebesar 
Hawa, et al/Jurnal Ekonomi Syariah Teori dan Terapan Vol.5 No. 12 Desember 2018: 998-1012; PENGARUH DPK, IMBAL HASIL SBIS, PUAS, DAN TINGKAT INFLASI TERHADAP PEMBIAYAAN BANK SYARIAH DI INDONESIA

0,000, sehingga dapat disimpulkan bahwa variabel independen secara simultan berpengaruh signifikan terhadap variabel dependen.

Langkah selanjutnya yaitu dengan melakukan Uji t. Uji $t$ digunakan untuk mengetahui pengaruh masing-masing variabel independen secara parsial terhadap variabel dependen, hasil uji $t$ ditunjukkan oleh tabel Coeficients.

Didalam Uji $t$ ini, yang harus diperhatikan adalah nilai dari unstandardized coefficients B untuk masing-masing variabel. Untuk variabel DPK, kita lihat memiliki nilai $\beta$ sebesar 0,753 yang artinya ketika DPK berubah 1 unit satuan, maka ceteris paribus pembiayaan akan berubah searah sebesar 0,753 satuan. Lalu pada nilai imbal hasil SBIS terlihat coefficients B sebesar 3019,998. Ini berarti bahwa ketika imbal hasil SBIS berubah 1 unit satuan, maka, ceteris paribus pembiayaan akan berubah searah sebesar 3019,998 satuan. Nilai $B$ pada PUAS sebesar 6,781. Ini berarti ketika PUAS berubah 1 satuan, maka ceteris paribus pembiayaan akan berubah sebanyak 6,781 satuan. Terakhir adalah tingkat inflasi yakni sebesar 14,725. Ini berarti pada saat tingkat inflasi berubah 1 satuan, maka tingkat inflasi berubah sebesar 14,725 satuan.

Signifikansi pegaruh variabel independen terhadap variabel dependen dapat dilihat dari nilai yang terdapat di kolom Sig. Nilai signifikansi yang $>0,05$ menyatakan bahwa $H_{0}$ diterima, dan jika siginifikansi $<0,05$ maka $H_{0}$ ditolak. Nilai signifikansi yang tertera pada tabel coefficients menunjukkan bahwa signifikansi DPK sebesar 0,000; itu berarti bahwa DPK berpengaruh secara signifikan terhadap pembiayaan, Imbal hasil SBIS sebesar 0,10 maka signifikan terhadap pembiayaan. Nilai signifikansi Imbal Hasil SBIS sebesar 0,10; hal tersebut menunjukkan Imbal Hasil SBIS berpengaruh secara signifikan terhadap pembiayaan. Selanjutnya, nilai signifikansi untuk variabel PUAS sebesar 0,002, dan hal ini menunjukkan bahwa PUAS berpengaruh secara signifikan terhadap pembiayaan. Terakhir, tingkat inflasi memiliki nilai signifikansi sebesar 0,005; dan hal tersebut menunjukkan variabel tingkat inflasi berpengaruh signifikan terhadap pembiayaan.

\section{Pengaruh DPK terhadap Pembiayaan Bank} Syariah

Hasil penelitian ini menunjukkan bahwa besar kecilnya DPK mempengaruhi penyaluran dana bank syariah. Bank yang memiliki DPK besar, memungkinkan untuk melakukan pembiayaan yang besar pula yang dapat menguntungkan pihak bank dalam menghasilkan laba dan bisa menjalankan operasionalnya setiap hari. Selain itu juga, DPK berpengaruh positif terhadap penyaluran dana bank syariah, artinya bank syariah mengandalkan pemasukan dana dari DPK untuk memenuhi pembiayaan. Dapat dibilang bahwa DPK merupakan sumber dana terbesar 
Hawa, et al/Jurnal Ekonomi Syariah Teori dan Terapan Vol.5 No. 12 Desember 2018: 998-1012; PENGARUH DPK, IMBAL HASIL SBIS, PUAS, DAN TINGKAT INFLASI TERHADAP PEMBIAYAAN BANK SYARIAH DI INDONESIA

sebagai modal bank syariah. Hal tersebut menyebabkan DPK menjadi faktor yang berpengaruh secara positif terhadap penyaluran dana bank syariah.

Pengaruh Imbal Hasil SBIS terhadap Pembiayaan Bank Syariah

Ketika Imbal Hasil SBIS naik maka pembiayaan bank syariah akan naik, ini dapat terjadi karena ketika bonus SBIS naik, maka bank syariah lebih tergiur menggunakan dananya untuk membeli SBIS yang relative tidak memiliki esiko seperti pembiayaan macet.

Pengaruh PUAS terhadap Pembiayaan Bank Syariah

PUAS mempunyai hubungan positif terhadap penyaluran dana bank syariah, sehingga hasil penelitian ini menunjukkan bahwa jika PUAS meningkat maka penyaluran dana bank syariah pun juga meningkat. Ini disebabkan karena dana yang tesedia di pasar vang dapat dibeli dengan menggunakan Sertifikat IMA oleh bank syariah dan disalurkan sebagai pembiayaan.

\section{Pengaruh Tingkat Inflasi terhadap Pembiayaan Bank Syariah}

Tingkat Inflasi akan mempengaruhi pula besar kecilnya penyaluran dana bank syariah. Namun sebenarnya pengaruh tingkat inflasi terhadap pembiayaan bank syariah dinilai cukup unik, dapat kita ketahui jika suatu negara mengalami inflasi dalam batas yang normal, maka keadaan perekonomian semakin meningkat dengan terpacunya para prosuden untuk meningkatkan hasil produksinya, selain itu masyarakat juga masih percaya dengan nilai vang dan masih mau memegang uang sehingga kegiatan penyaluran dana bank syariah masih bisa dilakukan. Namun jika inflasi sudah tinggi di dalam Negara tersebut, maka alasan bank semakin ingin mengeluarkan vangnya dengan cara penyaluran dana (pembiayaan), karena jika bank tetap menyimpan uangnya, maka nilai uang tersebut akan menguap oleh tingginya tingkat inflasi yang sedang terjadi.

Sehingga dapat disimpulkan di akhir bahwa semua variabel baik DPK, Imbal Hasil SBIS, PUAS, dan Tingkat Inflasi (variabel independen) berpengaruh signifikan terhadap pembiayaan (variabel dependen).

\section{Pengujian Asumsi Klasik \\ Uji Multikoliniearitas}

Hasil pengujian multikolinieritas dalam penelitian ini dapat diketahui dengan melihat tabel coefficients menggunakan SPSS Statistics version 24.

Pada tabel hasil uji multikolinieritas (tabel 4.9) terlihat bahwa angka VIF untuk variabel DPK sebesar 3,378, variabel imbal hasil SBIS sebesar 3,800, variabel PUAS sebesar 1,434, dan variabel tingkat inflasi sebesar 2,055. Semua nilai tolerance dari keempat variabel lebih dari 0,1.

$$
\text { Pada bagian Coefficients, }
$$
diketahui bahwa nilai VIF dari masingmasing variabel independen kurang dari 10 dan pada nilai tolerance dari masingmasing variabel lebih dari 0,1. Dari 
Hawa, et al/Jurnal Ekonomi Syariah Teori dan Terapan Vol.5 No. 12 Desember 2018: 998-1012; PENGARUH DPK, IMBAL HASIL SBIS, PUAS, DAN TINGKAT INFLASI TERHADAP PEMBIAYAAN BANK SYARIAH DI INDONESIA

kenyataan di atas dapat disimpulkan bahwa di antara variabel independen tersebut tidak terdapat korelasi atau tidak terjadi multikolinieritas pada model regresi linier.

\section{Uji Heteroskedatisitas}

Pengujian heteroskedatisitas dalam penelitian ini dilakukan dengan menggunakan SPSS Statistics version 24. Dari hasil uji heteroskedatisitas, terlihat titiktitik yang menyebar secara acak, dan tidak membentuk suatu pola tertentu yang jelas. Titik-titik tersebut menyebar baik di atas maupun di bawah angka 0 pada sumbu $Y$. Hal ini menunjukkan tidak terjadinya heteroskedatisitas pada model regresi linier berganda ini. Di pihak lain, model regresi linier berganda layak dipakai untuk melihat faktor-faktor pengaruh pembiayaan bank syariah di Indonesia.

\section{Uji Autokorelasi}

Persamaan yang baik adalah yang tidak memiliki masalah autokorelasi, jika terjadi autokorelasi maka persamaan tersebut menjadi tidak baik atau tidak layak dipakai. Masalah autokorelasi baru timbul jika ada korelasi secara linier antara kesalahan pengganggu periode $t$ (berada) dengan kesalahan pengganggu pada periode $t-1$ (sebelumnya). Salah satu ukuran dalam menentukan ada atau tidaknya masalah autokorelasi adalah uji Durbin-Watson (DW) dengan ketentuan sebagai berikut (Sunyoto, 2007, pp104105):
- Terjadi autokorelasi positif, jika DW $<-2$

- Tidak terjadi autokorelasi, jika $-2 \leq$ $\mathrm{DW} \leq 2$

- Terjadi autokorelasi negative, jika nilai $\mathrm{DW}>2$

Dari tabel Model Summary, terlihat bahwa hasil pengujian autokorelasi menunjukkan nilai Durbin Watson sebesar 0,423 . Hal ini menyatakan bahwa di dalam penelitian ini tidak terjadi autokorelasi, karena nilai Durbin-Watson berada di antara $-2 \leq \mathrm{DW} \leq 2$.

Kesimpulannya adalah persamaan ini baik dan layak untuk digunakan, karena tidak ada korelasi secara linier antara kesalahan pengganggu periode $\dagger$ (berada) dengan kesalahan pengganggu t-1 (sebelumnya).

\section{Uji Normalitas}

Setelah dilakukan uji statistik normalitas, maka didapatkan hasil berupa sebuah grafik. Dasar pengembalian keputusan dengan menggunakan analisis grafik menurut Ghozali (2011:163) adalah:

a. Jika data menyebar di sekitar garis diagonal dan mengikuti arah garis diagonal atau grafik histogramnya menunjukkan pola distribusi normal, maka model regresi memenuhi asumsi normalitas.

b. Jika data menyebar jauh dari grafis diagonal dana/tidak mengikuti arah garis diagonal atau grafik histogram tidak menunjukkan pola distribusi 
Hawa, et al/Jurnal Ekonomi Syariah Teori dan Terapan Vol.5 No. 12 Desember 2018: 998-1012; PENGARUH DPK, IMBAL HASIL SBIS, PUAS, DAN TINGKAT INFLASI TERHADAP PEMBIAYAAN BANK SYARIAH DI INDONESIA

normal, maka model regresi tidak memenuhi asumsi normalitas.

Berdasarkan hasil uji, terlihat bahwa data menyebar di sekitar garis diagonal dan mengikuti arah garis diagonal. Dapat disimpulkan bahwa grafik P-P Plot menunjukkan data terdistribusi secara normal.

\section{SIMPULAN DAN SARAN \\ SIMPULAN}

1. Hipotesis dalam penelitian ini terbukti.

2. A. Dana Pihak Ketiga (DPK) berpengaruh positif signifikan secara parsial terhadap penyaluran dana bank syariah.

B. Imbal Hasil SBIS berpengaruh positif signifikan secara parsial terhadap penyaluran dana bank syariah.

C. Pasar Uang Antarbank Syariah (PUAS) berpengaruh positif signifikan secara parsial terhadap penyaluran dana bank syariah .

D. Tingkat Inflasi berpengaruh postif signifikan secara parsial terhadap penyaluran dana bank syariah

3. Sebesar $98,5 \%$ penyaluran dana bank syariah dijelaskan oleh DPK, Imbal Hasil SBIS, PUAS, dan Tingkat Inflasi. Sedangkan, sisanya sebesar $1,5 \%$ dijelaskan oleh variabel lain diluar variabel independen yang digunakan dalam penelitian.

\section{SARAN}

1. Variabel independen yang digunakan dalam penelitian ini hanya sebatas DPK, Imbal Hasil SBIS, PUAS, dan Tingkat Inflasi. Pada penelitian selanjutnya diharapkan memasukkan variabel-variabel lain yang berpengaruh terhadap penyaluran dana bank syariah.

2. Saran untuk penelitian selanjutnya terkait dengan penyaluran dana bank syariah adalah memperluas tema penelitian, meneliti salah satu bank syariah secara khusus, maupun memperpanjang periode penelitian di penelitian selanjutnya.

\section{DAFTAR PUSTAKA}

Ascarya, 2012. Buletin Ekonomi dan Perbankan: Alur Transmisi Kebijakan Moneter Ganda di Indonesia. Jurnal Ekonomi Islam Republika

Anshori, Muslich dan Sri Iswati. 2009. Buku Ajar Metodologi Penelitian Kuantitatif. Surabaya: Airlangga University Press.

Arifin Z. 2009. Dasar-dasar Manajemen Bank Syariah. Jakarta(ID): Azkia Publisher.

Dahlan, Rahmad. 2014. Pengaruh Tingkat Bonus Sertifikan Bank Indonesia Syariah dan Tingkat Inflasi Terhadap Pembiayaan Bank Syariah Di Indonesia. Jurnal Etikonomi Vol. 13 No. 2.

Danang, Sunyoto. 2007. Metodologi Penelitian Ekonomi, Cetakan Pertama. CAPS. Yogyakarta.

Dendawijaya, Lukman. 2009. Manajemen Perbankan. Jakarta: Pernebit Ghalia Indonesia

Ghozali, I. (2011). Aplikasi Analisis Multivariate dengan Program IBM SPSS 19. Semarang: Universitas Diponegoro. 
Karim, Adiwarman A. 2007. Ekonomi Makro Islam. Jakarta: PT Raja Grafindo Persada.

Karnaen, Perwaatmadja dan M.Syafi'l Antonio. 1997. Apa dan Bagaimana Bank Islam. Yogyakarta: Dana Bhankti Wakaf.

Kuncoro, Mudrajat. 2003. Metode Riset untuk Bisnis \& Ekonomi, Bagaimana Meneliti \& Menulis Tesis. Erlangga, Jakarta.

Peraturan Bank Indonesia No.6/7/PBI/2004 tentang SWBI

Peraturan Bank Indonesia No. 10/18/PBI/2010 tentang SBIS

Peraturan Bank Indonesia No. 12/19/PBI/2010 tentang Dana Pihak Ketiga

Putong, Iskandar. 2003. Pengantar Ekonomi Mikro dan Makro. Ghalia Indonesia

Undang-undang Republik Indonesia Nomor Nomor 7 Tahun 1992 tentang Perbankan
Undang-undang Republik Indonesia Nomor Nomor 10 Tahun 1999 tentang Perbankan

Samuelson, Paul. A and Willam D. Nordhaus. 1995. Economics Fifteen Edition. New Baskerville: York Graphic Services, Inc.

Santoso, Singgih. 2000. Latihan SPSS Statistik Parametrik. Jakarta: PT Elex Media Komputindo.

Sudarsono, Heri. 2005. Bank dan Lembaga Keuangan Syariah. Yogyakarta EKONISIA.

Sujarweni, V. Wiratna. 2014. SPSS Untuk Penelitian. Yogyakarta: Pustaka Baru Press

Sukirno, Sadono, Makroekonomi: Teori Pengantar, Jakarta: Raja Grafindo Persada, 2004.

Tri Basuki, Agus. 2016. Analisis Regresi dalam Penelitian Ekonomi dan Bisnis, Jakarta: Rajawali Pers.

Widyatsari, Any. 2014. Pasar Uang Antar Bank Syariah. Economic: Jurnal Ekonomi dan Hukum Islam. 


\section{Lampiran}

Sumber: SPSS Version 24.

Tabel 1.

Model Summaryb

\begin{tabular}{|c|c|c|c|c|c|}
\hline Model & $\mathrm{R}$ & R Square & $\begin{array}{c}\text { Adjusted R } \\
\text { Square }\end{array}$ & $\begin{array}{l}\text { Std. Error of } \\
\text { the Estimate }\end{array}$ & Durbin-Watson \\
\hline 1 & $.992 a$ & .985 & .984 & 4752.68623 & .423 \\
\hline
\end{tabular}

a. Predictors: (Constant), inflasi, dpk, puas, imbal_hasil

b. Dependent Variable: total_pembiayaan

Tabel 2.

ANOVAa

\begin{tabular}{|c|c|c|c|c|c|}
\hline \multicolumn{1}{|c|}{ Model } & Sum of Squares & $\mathrm{df}$ & Mean Square & $\mathrm{F}$ & Sig. \\
\hline $1 \quad$ Regression & 79870639060.000 & 4 & 19967659770.000 & 883.993 & $.000^{\mathrm{b}}$ \\
Residual & 1242341451.000 & 55 & 22588026.380 & & \\
Total & 81112980510.000 & 59 & & & \\
\hline
\end{tabular}

a. Dependent Variable: total_pembiayaan

b. Predictors: (Constant), inflasi, dpk, puas, imbal_hasil

Tabel 3.

\section{Coefficients ${ }^{a}$}

\begin{tabular}{|c|c|c|c|c|c|c|c|c|c|c|}
\hline & $\begin{array}{r}\text { Unstanc } \\
\text { Coeff }\end{array}$ & $\begin{array}{l}\text { ardized } \\
\text { cients }\end{array}$ & $\begin{array}{c}\text { Stan } \\
\text { dard } \\
\text { ized } \\
\text { Coe } \\
\text { fficie } \\
\text { nts } \\
\end{array}$ & & & \multicolumn{3}{|c|}{ Correlations } & \multicolumn{2}{|c|}{$\begin{array}{c}\text { Collinearity } \\
\text { Statistics }\end{array}$} \\
\hline Model & B & Std. Error & Beta & $\dagger$ & Sig. & $\begin{array}{c}\text { orde } \\
\mathrm{r}\end{array}$ & $\begin{array}{c}\text { Parti } \\
\text { al }\end{array}$ & Part & $\begin{array}{c}\text { Tolera } \\
\text { nce }\end{array}$ & VIF \\
\hline 1 (Constant) & 8592.706 & 3820.880 & & 2.249 & .029 & & & & & \\
\hline
\end{tabular}


Hawa, et al/Jurnal Ekonomi Syariah Teori dan Terapan Vol.5 No. 12 Desember 2018: 998-1012; PENGARUH DPK, IMBAL HASIL SBIS, PUAS, DAN TINGKAT INFLASI TERHADAP PEMBIAYAAN BANK SYARIAH DI INDONESIA

\begin{tabular}{c|c|c|c|c|c|c|c|c|c|c|} 
dpk & .753 & .026 & .898 & 29.279 & .000 & .980 & .969 & .489 & .296 & 3.378 \\
imbal_hsl & 3019.998 & 1130.297 & .087 & 2.672 & .010 & .776 & .339 & .045 & .263 & 3.800 \\
puas & 6.781 & 2.039 & .066 & 3.325 & .002 & .529 & .409 & .055 & .697 & 1.434 \\
inflasi & 14.725 & 5.011 & .070 & 2.938 & .005 & .023 & .368 & .049 & .487 & 2.055 \\
\hline
\end{tabular}

a. Dependent Variable: total_pembiayaan

\section{Gambar 1}

\section{Scatterplot}

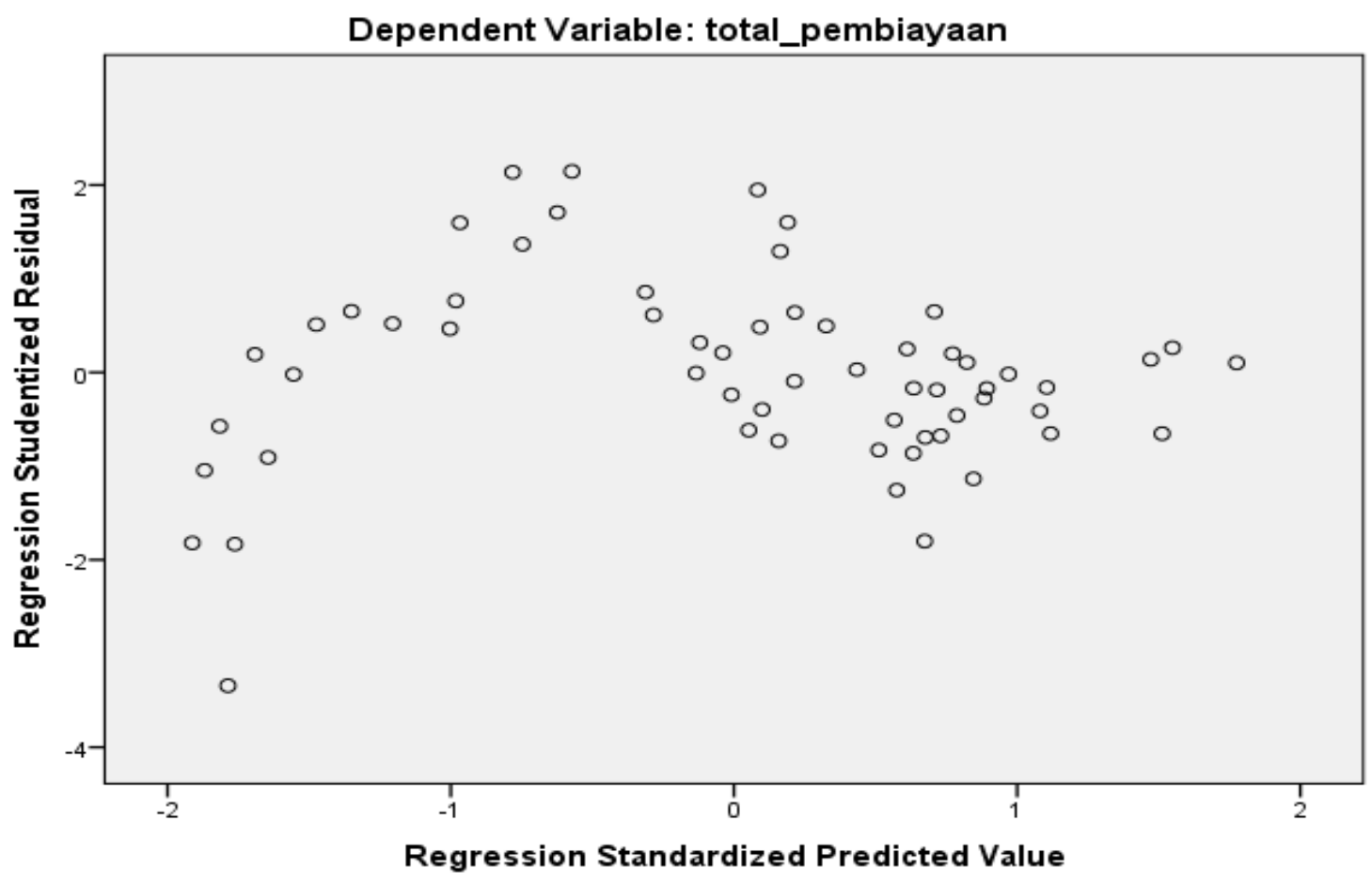

Gambar 2. 
Hawa, et al/Jurnal Ekonomi Syariah Teori dan Terapan Vol.5 No. 12 Desember 2018: 998-1012; PENGARUH DPK, IMBAL HASIL SBIS, PUAS, DAN TINGKAT INFLASI TERHADAP PEMBIAYAAN BANK SYARIAH DI INDONESIA

Normal P-P Plot of Regression Standardized Residual

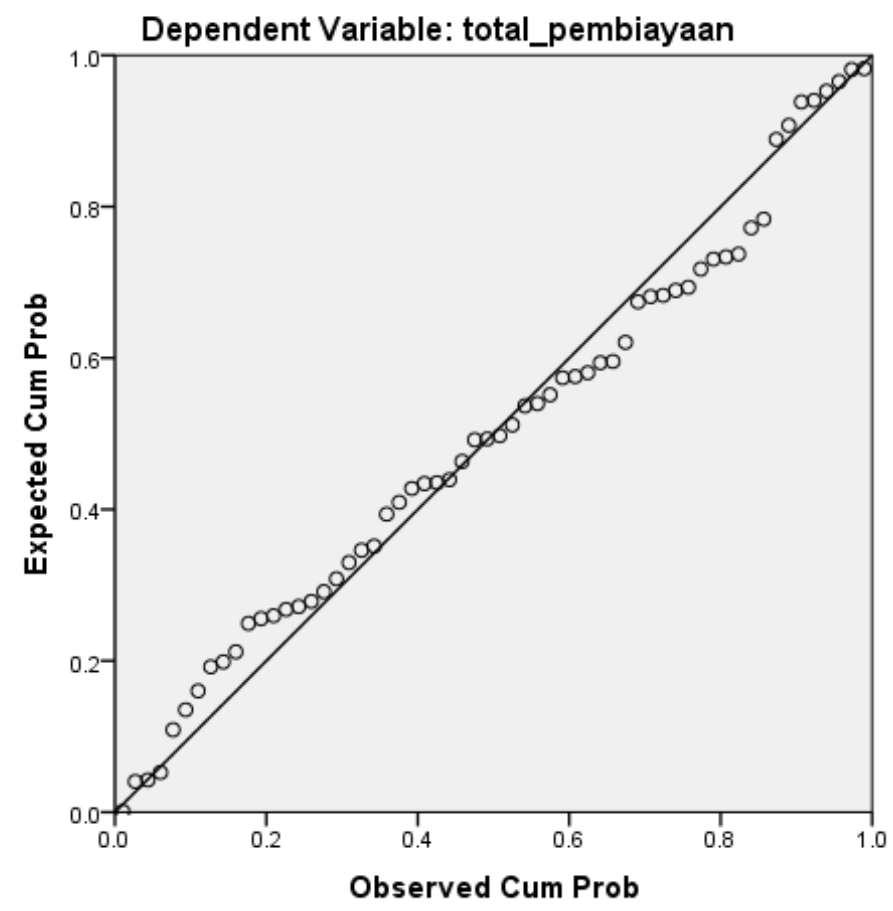

